\title{
Variability of some isolates of Prunus necrotic ringspot virus and Prune $d$ warf virus infecting sour and sweet cherry in Ukraine
}

\author{
Liliia PAVLIUK ${ }^{1,2}$, Kateryna UDOVYCHENKO ${ }^{1}$, Iryna RIABA ${ }^{1}$, Mykola BUBLYK ${ }^{1}$
}

Received August 20, 2020; accepted February 10, 2021. Delo je prispelo 20. avgusta 2020, sprejeto 10. februarja 2021.

Variability of some isolates of Prunus necrotic ringspot virus and Prune dwarf virus infecting sour and sweet cherry in Ukraine

Abstract: Prunus necrotic ringspot virus (PNRSV) and Prune dwarf virus (PDV) are the most common pathogens in stone crop orchards. These diseases are easily transmitted with pollen and hence rapidly spread in orchards leading to stunting of trees, their increased susceptibility to abiotic stress factors and, eventually, to significant yield losses. In Ukraine, only monitoring studies on the spread of these viruses were conducted until now. However, phylogenetic comparison of Ukrainian isolates was lacking. In this work, total RNA was isolated from plant samples tested positive for PNRSV and PDV by ELISA. The part of viral CP gene sequences were amplified and sequenced with their subsequent phylogenetic analysis. It was determined that PNRSV isolates from Ukraine analyzed in this study belong to different groups - PV-96 (MT828889) and PV32 (MT892676) with a maximum identity level of $100 \%$ with known isolates from NCBI GenBank. PDV isolates (MT828888 and MT828887) showed high identity with each other (99.6\%), and Slovakian isolate from sweet cherry was shown as the most related to them with identity of $95.3 \%$.

Key words: PNRV; PDV; ELISA; RT-PCR; sweet cherry virus; phylogenetic analysis
Variabilnost izolatov virusa nekrotične obročkaste pegavosti breskve (PNRSV) in virusa pritlikavosti slive (PDW) na višnji in češnji v Ukrajini

Izvleček: Virus nekrotične obročkaste pegavosti breskve (PNRSV) in virus pritlikavosti slive (PDW) sta najbolj pogosta patogena $\mathrm{v}$ sadovnjakih koščičastega sadja. Bolezni se z lahkoto prenašata $s$ cvetnim prahom in se tako hitro širita v sadovnjakih, kar vodi k slabitvi dreves, povečuje njihovo občitljivost na abiotske stresorje in včasih k znatni izgubi pridelka. V Ukrajini so bile do sedaj izvedene le raziskave o razširjenosti teh virusov, ni pa bilo njihovih filogentskih raziskav.V tej raziskavi so bili z ELISA testom analizirani izolati iz vzorčenih rastlin, pozitivnih na PNRSV in PDV. Del zaporedij virusovega CP gena je bilo namnoženih in sekvenciranih za njihovo kasnejšo filogenetsko analizo. Ugotovljeno je bilo, da izolati PNRSV virusov iz Ukrajine, analizirani v tej raziskavi, pripadajo različnim skupinam in sicer skupinama PV-96 (MT828889) in PV-32 (MT892676) $\mathrm{z}$ največjo stopnjo istovetnosti $100 \% \mathrm{z}$ znanimi izolati iz NCBI GenBank. PDV izolata (MT828888 in MT828887) sta pokazala veliko medsebojno istovetnost (99.6\%), in s slovaškim izolatom iz češnje, ki se je izkazal najbolj soreden $\mathrm{z}$ njima $\mathrm{z}$ istovetnostjo $95.3 \%$.

Ključne besede: PNRV; PDV; ELISA; RT-PCR; češnjev virus; filogenetska analiza

1 Institute of Horticulture of National Academy of Agrarian Sciences of Ukraine, Novosilky, Kyiv region, 03027, Ukraine

2 Corresponding author, e-mail: pavliukl.92@ukr.net 


\section{INTRODUCTION}

Sour cherry (Prunus cerasus L.) and sweet cherry (Prunus avium L.) are traditional fruit crops in Ukraine. They have an important role in the structure of fruit and berry crop production. According to the State Statistics Service of Ukraine (http://www.ukrstat.gov.ua/), the volume of sour and sweet cherry production in Ukraine in 2019 amounted to 236.13 thousand tons. However, virus diseases are one of the limiting factors for increasing yields.

The most common sour and sweet cherry viruses in the world are Prunus necrotic ringspot virus (PNRSV) and Prune dwarf virus (PDV) (Caglayan et al., 2011). According to the preliminary data, prevalence of these viruses in mother plant orchard of cherries in Ukraine is $11.8 \%$ for PNRSV and $8.7 \%$ for PDV (Pavliuk et al., 2018). Both viruses belong to Ilarvirus genus, Bromoviridae family (Pallas et al., 2012). In fruit trees, infection by these viruses leads to a variety of symptoms, the manifestation of which depends on climatic conditions and the type of host plant (Kamenova et al., 2019).

PDV causes chlorotic rings and spotting, deformation (thinning and curling) of leaf blades, and shortening of internodes (Kamenova et al., 2019). PNRV induce similar symptoms to PDV, and is also manifested by necrotic and chlorotic spots, mosaic and deformation of leaves, flowers and fruits, but often remains latent (Sokhandan-Bashir et al., 2017). PNRSV symptoms may vary depending on the time passed since the initial infection. Immediately after the virus enters the plant ("shock phase"), the most acute necrotic symptoms are typically observed. In the following chronic course of the disease, the symptoms may be partially masked or slightly altered. Also, in the initial infection, the virus delays the flowering on individual branches or of the whole tree, and young leaves are often smaller than those of healthy plants. The spotting pattern may vary depending on the cultivar (Verderevskaya \& Marinesku, 1985; Nyland et al., 1976; Wells \& Kirkpatrick, 1986).

Mixed infection of plants with PDV and PNRSV leads to the development of more severe symptoms (Caglayan et al., 2011). These two viruses are often found in combination as both are readily transmitted by pollen.

These pathogens are particularly dangerous for sour and sweet cherry, peach, and almond (Umer et al., 2019). Crop yield is reduced due to the decrease in the number of fruit buds caused by these two viruses (Kamenova et al., 2019). Under the influence of these pathogens, peach yield can be reduced by $60 \%$ (Umer et al., 2019). Infection of Prunus spp. plants by PNRSV reduces tree growth by $30 \%$, and reduces yield by $20-56 \%$, also making the trees very susceptible to low temperatures (Amari et al., 2007).

In susceptible crops, PDV monoinfection can cause yield losses of up to $99 \%$, also significantly reducing fruit quality (Çağlayan et al., 2011).

In addition to transmission by grafting and other agronomic measures, spreading by pollen is a typical way of transmission (Çağlayan et al., 2011; Pallas et al., 2012). Due to their ability to transmit by pollen, PDV and PNRSV can spread rapidly in stone crop orchards and cause significant economic damage (Amari et al., 2007; Çağlayan et al., 2011; Kamenova et al., 2019; Nemeth, 1986; Umer et al., 2019).

As other ilarviruses, these pathogens have segmented genome consisting of three fragments of single-stranded positive sense RNA (Pallas et al., 2012; Roosinck et al., 2005). PNRSV has isometric virions (Jakab-Ilyefalvi et al., 2011) while PDV can form two types simultaneously - icosahedral and bacilli forms (Kozieł et al., 2017).

RNA1 and RNA2 encode replicase subunits, while RNA3 encodes coat protein (CP) and movement protein (MP). The CP is synthesized from subgenomic RNA (RNA4) derived from RNA3 (Pallas et al., 2012). $\mathrm{CP}$ of ilarviruses forms a shell for packaging of genome segments and participates in its activation (Pallas et al., 2013). RNA3 length is $1683 \mathrm{nt}$ for PDV and 1943 or $1951 \mathrm{nt}$ for PNRSV. Ilarvirus MP is required for virus cell-to-cell trafficking (Pallas et al., 2012). For phylogenetic analysis of ilarviruses, CP or MP gene sequences are typically used (Codoñer \& Elena, 2006), or partial sequences of $R d R p$ (Maliogka et al., 2007).

Viral genome variability contributes to the emergence of new highly virulent isolates, so there is a need for phylogenetic analysis, which allows to determine the variability of the genome and to establish its genetic identity with already known isolates. The aim of the research was to analyse part of CP gene of Ukrainian PNRSV and PDV isolates sampled from sour and sweet cherry trees, and to establish their phylogenetic relationships with known isolates by comparing the nucleotide sequences.

\section{MATERIALS AND METHODS}

In order to identify the symptoms of viral infection, a visual examination of the mother plantations was performed during the period of the most pronounced manifestation of symptoms - May-June of 2019 year. In order to confirm the presence of viral infection, leaf samples were taken from four spots in tree canopy.

Samples were taken (Table 1) from plants with symptoms typical for to PDV and PNRSV infections, as well as from asymptomatic plants. The latter were select- 
ed from trees near to those having the most expressed symptoms. Positive samples previously tested by ELISA were confirmed by RT-PCR. One sample from each infected cultivar was taken for sequencing. These samples included those from sour cherry cultivars Kseniia (PNRSV), Boguslavka (PDV), and a sample of sweet cherry Nizhnist cultivar (PDV and PNRSV).

Extraction of total RNA was performed using RNeasy Plant Mini kit (Qiagen, UK) according to the manufacturer's recommendations. $75 \mathrm{mg}$ of fresh tissue was used for extraction. Extracted RNA was stored at $-20^{\circ} \mathrm{C}$. Extraction quality was checked by DeNovix DS- 11 spectrophotometer (DeNovix, USA), at wavelength of 260 , 260/230, 260/280 nm.

PNRSV and PDV identification was carried out by RT-PCR using primer pairs amplifying a part of CP gene: $P N R S V-10 F$ (5'-TTC TTG AAG GAC CAA CCG AG AGG-3')/PNRSV-10R (5'-GCT AAC GCA GGT AAG ATT TCC AAG C-3') with expected fragment size of $348 \mathrm{bp}$, and $P D V-17 \mathrm{~F}$ (5'-CGA AGT CTA TTT CCG AGT GGA TGC-3')/PDV-12R (5'-CAC TGG CTT GTT TCG CTG TGA AC-3') with the expected fragment size of 303 bp (Massart et al., 2008.) In order to control RNA amplification, internal control with nad5-f/nad5-r primers with expected fragment size of 181 bp was used (Menzel et al., 2002).

In order to conduct RT-PCR, commercial kit Verso 1-Step RT-PCR Kit ReddyMix (Thermo Scientific, USA) was used according to the manufacturer's recommendations. The following components were taken per reaction mixture with a volume of $20 \mu \mathrm{l}$ : 2X 1 Step PCR ReddyMix - $10 \mu \mathrm{l}$, Verso Enzyme Mix - 0,4 $\mu \mathrm{l}$, RT Enhancer - $1 \mu \mathrm{l}$, Primer forward - 0,4 $\mu \mathrm{l}$ (10 mmol), Primer reverse - 0,4 $\mu \mathrm{l}(10 \mathrm{mmol}), \mathrm{H}_{2} \mathrm{O}-$ $6,6 \mu \mathrm{l}, \mathrm{RNA}-50 \mathrm{ng}$ for one reaction. The same reaction was performed to check RNA quality with nad5-f/nad5$r$ primers. Amplification was performed in «Eppendorf Mastercycler Personal» programming thermostat (Eppendorf AG, Germany) with the following parameters: $50^{\circ} \mathrm{C}-15$ minutes, $95^{\circ} \mathrm{C}-2$ minutes, 40 amplification cycles $\left(95^{\circ} \mathrm{C}-20 \mathrm{~s}, 55^{\circ} \mathrm{C}-30 \mathrm{~s}, 72{ }^{\circ} \mathrm{C}-15 \mathrm{~s}\right)$, and $72{ }^{\circ} \mathrm{C}-5$ minutes.

The presence of amplification fragments was checked by separating the PCR products in $2 \%$ agarose gel, with TBE buffer with the addition of ethidium bromide $0.5 \mu^{-1}$.

Obtained amplicons of domestic isolates of the Ilarvirus genus were sequenced by Sanger sequencing method. The sequences of PNRSV and PDV capsid protein gene were compared with the known sequences in GenBank (www.ncbi.nlm.nih.gov) using function BLAST 2.10.0 software. For phylogenetic analysis, 25 PNRSV and 30 PDV isolates were selected from the GenBank (www.ncbi.nlm.nih.gov), that were extracted from different crops and geographic origin. Multiple sequence alignments were performed by Clustal W algorithm of MEGA 10 (Kumar et al., 2018). Sequences were cut corresponding to the length of our fragment. Construction of the phylogenetic tree was carried out using MEGA 10 software by the methods Neighbour-Joining (NJ) (Saitou \& Nei, 1987) using Kimura two parameter. The statistical significance was calculated using 500 bootstrap replicates (Felsenstein, 1985). Standard error of the pairwise identities of groups was calculated using STATISTICA software.

\section{RESULTS AND DISCUSSION}

Careful examination of the trees revealed leaf de-

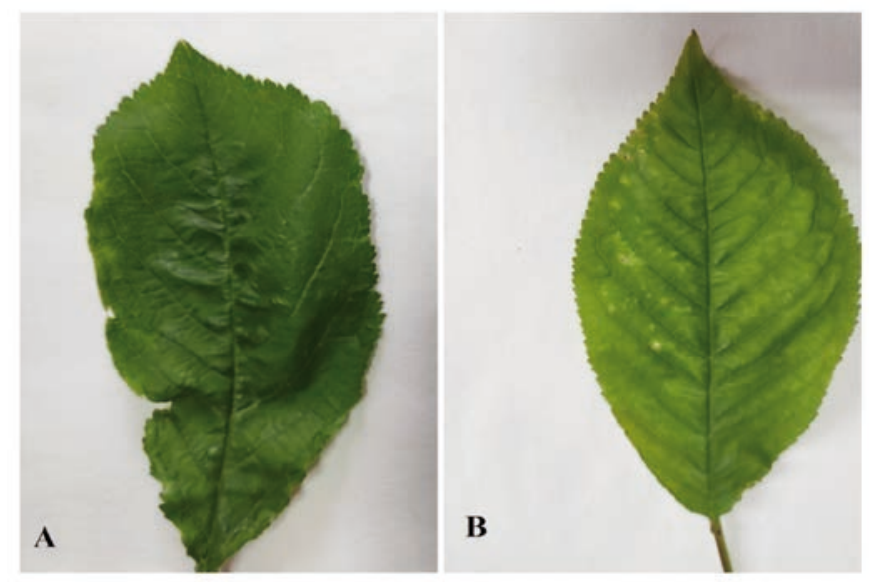

Figure 1: Chlorosis and deformation of the leaf. A - 'Boguslavka' (PDV infected), B - 'Nizhnist' (PDV and PNRSV infected) (virus isolates recovered from these samples were used for phylogenetic analysis) 
formations along the veins (Fig. 1A), dark brown spots with small holes and chlorotic areas. It should be noted that chlorosis was the most common symptom among all surveyed trees. These symptoms are characteristic of PDV infection and have been repeatedly described by a number of authors (Massart et al., 2008; Smith et al., 1988; Sanchez et al., 2015; Kamenova et al., 2019).

Chlorotic spots and small necrotic holes were detected on sweet cherry of 'Nizhnist' cultivar (Fig. 1B). The presence of both viruses in the plant was confirmed by ELISA and RT-PCR.

The course of viral diseases is often latent and displays no symptoms of infection. This is especially true when the disease becomes chronic. Therefore, the examination of 'Kseniia' sour cherry trees did not reveal any symptoms of virus infection, although ELISA and RTPCR diagnostics confirmed virus presence.

Despite many trees showing symptoms similar to virus infection, the presence of pathogens was not confirmed in all samples. This is because the symptoms of virus infection can be very similar to the effects of abiotic factors, lack of nutrients, insect damage etc.
After preliminary ELISA testing, in order to study the molecular characteristics samples were selected: 'Kseniia' infected with PNRSV, 'Bohuslavka' - with PDV and 'Nizhnist' with mixed infection of these viruses (Table 1).

Isolates were named based on the position of infected trees in the orchard. RT-PCR method confirmed the presence of viruses in the tested samples (Fig. 2). As a result, the sequences of isolates PNRSV 4-1 (828889), PNRSV 16-15 (MT892676), PDV 1-67 (MT828888), PDV 16-15 (MT828887) were obtained.

Sequenced fragments of the PNRSV coat protein gene after its alignment had 295 nucleotides corresponding to nts 1601-1891 in RNA3. This part contains a $177 \mathrm{nt}$ part of the coding region (nts 1601-1777) and a part of UTR. The sequenced fragment of the genome of the Ukrainian isolates PNRSV 4-1 and PNRSV 16-15, which is the C-terminal end of the CP gene, is extremely conserved as it includes the dimerization region at position of 1694-1744 nt (198-215 amino acids) (Aparicio et al., 2006). It should be noted that the presence of a non-coding sequence does not affect the phylogenetic grouping of isolates.

Table 1: Sour and sweet cherry samples tested for PDV and PNRSV by ELISA method

\begin{tabular}{llllll}
\hline & \multirow{2}{*}{$\begin{array}{l}\text { Number of tested } \\
\text { samples (n) }\end{array}$} & PDV & PNRV & Mixed infection \\
\cline { 3 - 5 } Cultivar & 6 & - & - & 1 & Zaporizhzhya \\
\hline Nizhnist (sweet cherry) & 7 & - & - & - & Zaporizhzhya \\
Vidrodzhennia (sour cherry) & 7 & 4 & - & - & Kyiv \\
Boguslavka (sour cherry) & 11 & - & 3 & - & Kyiv \\
Kseniia (sour cherry) & 7 & - & - & - & Kyiv \\
Malva (sour cherry) & 4 & 4 & 1 & - \\
Total & 35 & 4 & 3 & \\
\hline
\end{tabular}

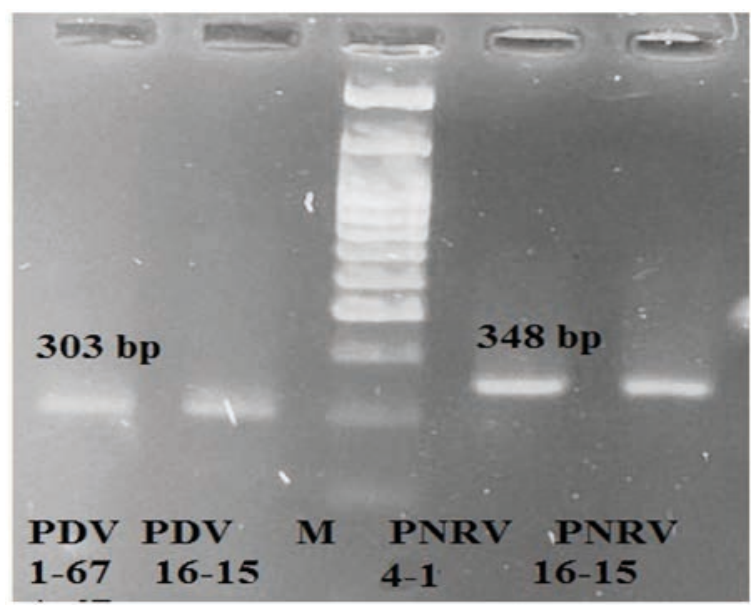

Figure 2: Fragments amplified from extract of infected sour and sweet cherry samples, M - SibEnzyme 100bp molecular weight marker 
Based on the molecular characteristics of the nucleotide sequences of the CP and MP genes, PNRSV isolates are divided into three groups: PV32, PE5 and PV96 (Pallas et al., 2012). According to the results of the analysis, Ukrainian isolates extracted from cherry cultivars were attributed to two different groups. PNRSV 4-1 isolate fell into PV96 group while PNRSV 16-15 - into PV32 group. Isolates belonging to the PV96 group are characterized by asymptomatic course of infection, while PV32 can cause severe disease symptoms, and PE- 5 can cause both mild and severe symptoms. However, information on pathogenicity of isolates is limited, so virus group affiliation and respective symptoms do not necessarily correlate (Hammond, 2003). In our case, trees of 'Kseniia' infected by the isolate of PV96 group did not show infection symptoms, while the plant of 'Nizhnist' the symptoms were apparent. In the latter case, we cannot say for sure that such manifestation of symptoms depends on the aggressiveness of the isolate, as this sample was also infected with PDV.

The identity between the nucleotide sequences of the whole investigated fragment of PNRSV 4-1 and PNRV $16-15$ isolates was $97.9 \%$, but was $100 \%$ at the amino acid level. The non-coding section turned out to be the most variable $95.5 \%$ identity between the isolates. The identity between the coding fragments was $98.7 \%$. The difference of $1.3 \%$ between domestic isolates is caused by two nucleotide T/C substitutions that occurred at positions 1642 and $1714 \mathrm{nt}$.

During the construction of the phylodendrogram, three main clusters were formed. The first cluster (Fig. 3) consisted of 12 isolates representing the PV-96 group, including PNRSV 4-1 isolate. The identity of this isolate with other from the same group ranged from 100 to $99.3 \%$ at the nucleotide level. The most similar isolates were sAJ133205.1 (peach, Italy), AJ133208.1 (nectarine, Spain), JQ005044.1 and JQ005057.1 (sweet cherry and peach, Canada), MH730938.1 (peach, China). The range of pairwise identities within this group was $99.7-99.3 \%$. This indicates nucleotide substitutions that occur in the middle of the group.

PNRSV 16-15 isolate from Ukraine belongs to PV32 group in its molecular characteristics. In addition to the Ukrainian isolate, the group includes 10 isolates from the NCBI GenBank. Of this group, the most similar isolates were AJ133213.1 (plum, Italy), MF069040.1 (sweet cherry, Czech Republic), AY948440.1 (rose, In-

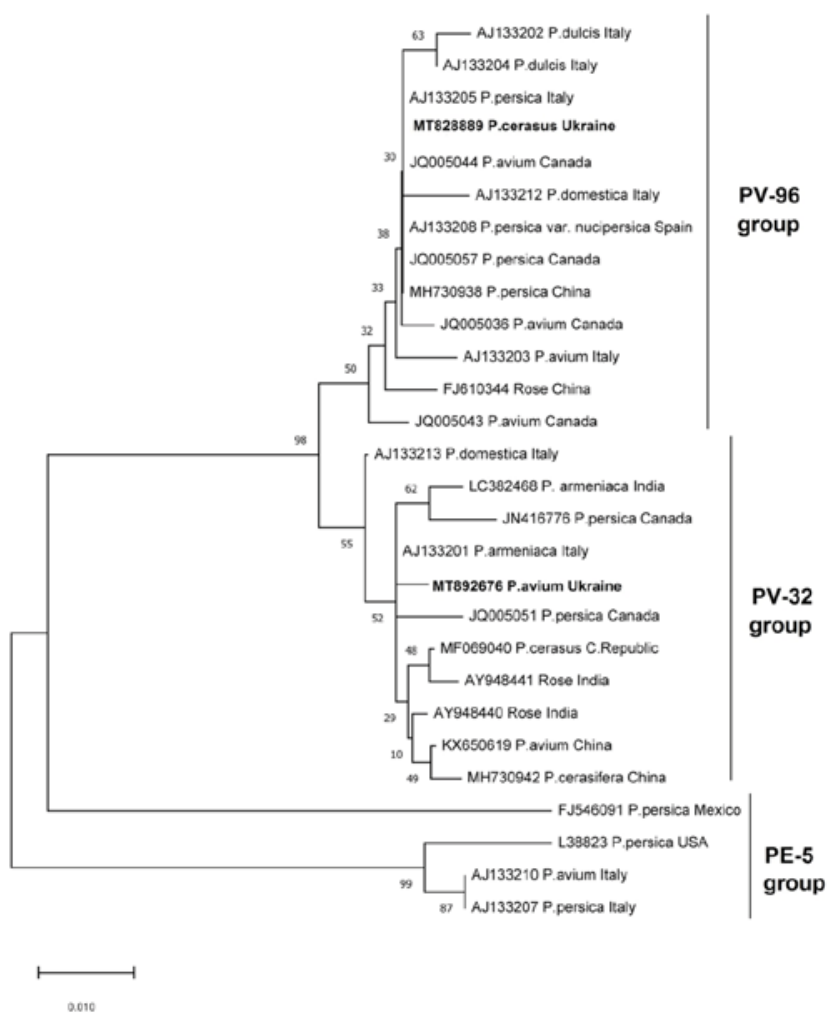

Figure 3: Phylogenetic tree of PNRV isolates, constructed on the basis of sequences of fragments of the CP gene and the UTR using the Neighbour-Joining algorithm option of MEGA 10. Bootstrap analysis of 500 replicates was performed. Sequences obtained in our study are highlighted in bold. The scale bar represents the number of substitutions per nucleotide. 
dia), KX650619.1 (sweet cherry, China). Other members of this group were 99.6-98.6\% identical to PNRSV 16-15.

Comparison of the nucleotide sequences of the isolates detected nucleotide substitutions, both within the group and between groups. These substitutions were synonymous and did not affect the amino acid sequence. All isolates included in PV 96 and PV32 groups were $100 \%$ identical at the amino acid level.

When comparing this section of the representatives of the two groups, a total of 13 nucleotide substitutions were found which did not affect the amino acid sequence.

The PE-5 group stood out separately. Isolates of this group were characterized by low identity with PV groups. The identity of Ukrainian isolates with representatives of PE-5 was 90.3-91.5 \% with PNRSV 4-1 and 89.8-90.7\% with PNRSV 16-15

The analysis showed that the grouping of isolates does not depend on the geographical origin and the host plant. The same conclusions were made in previous studies (Aparicio et al., 1999; Aparicio \& Pallás, 2002; Scott et al., 1998), as CP is highly conservative and does not depend on the host plant or geographical area (Sala-Rejczak \& Paduch-Cichal, 2013).

Sequenced fragment of the coat protein of PDV with a size of $262 \mathrm{nt}$, which corresponds to the position of 1340-1601 nt in RNA3. This section encodes 87 amino acids at the position 43-129. The studied fragment is part of ORF3b (Kozieł et al., 2017; Bahman et al., 1994).

When comparing the fragment of the nucleotide sequence of PDV 1-67 and PDV 16-15 isolates, the identity was at the level of $99.6 \%$, while for the amino acids - $98.8 \%$. A single nucleotide substitution in PDV 1-67 isolate $-\mathrm{A} / \mathrm{T}$ at position 1455 resulted in the replacement of the amino acid F (phenylalanine) / Y (tyrosine) at position 81 . It should be noted that these substitutions were absent in all other isolates. Also, Ukrainian isolates were characterized by the presence of $\mathrm{C}$ nucleotide at position 1519, while all other isolates had $\mathrm{T}$ in this position. However, this replacement was synonymous and did not change the protein composition. The range of pairwise identities of PDV 1-67 and PDV 16-15 to other isolates was quite wide and ranged from 95.3 to $85.9 \%$ at the nucleotide level, which indicates a fairly high variability of the genome of isolates. Amino acid sequence identity was slightly higher at 97.7-86.5\%, indicating that some amino acid substitutions were still synonymous. In total, in the analysis of all studied isolates, 24 positions in which amino acid substitutions took place were calculated.

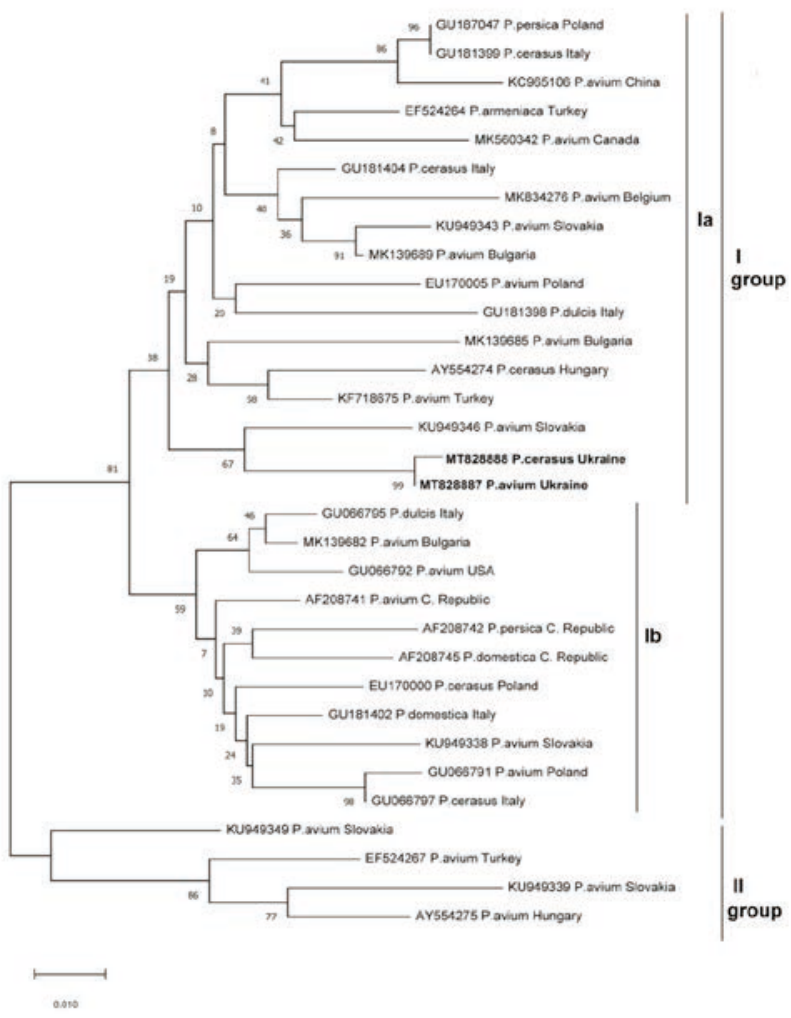

Figure 4: Phylogenetic tree of PDV isolates, constructed on the basis of sequences of fragments of the CP gene using the NeighbourJoining algorithm option of MEGA 10. Bootstrap analysis of 500 replicates was performed. Sequences obtained in our study are highlighted in bold. The scale bar represents the number of substitutions per nucleotide. 
When constructing a phylogenetic tree, all isolates were divided into two main groups (Fig. 4). The first group included two subgroups. Subgroup Ia consisted of 17 isolates, which differed in geographical origin and host plant. The Ia subgroup also included Ukrainian isolates. KU949346 isolate (sweet cherry, Slovakia) was the closest in amino acid and nucleotide sequences. The level of identity by nucleotide sequences was $95.3 \%$ with PDV 16-15 and 94.9\% with PDV 1-67 and 98.8 and $97.7 \%$ by amino acid sequences, respectively. Identity of this subgroup with other isolates varied between 94.4-88.3\%, while the mean pairwise identity within this subgroup was $93.81 \%$. Subgroup Ib included 11 isolates. The range of pairwise identities with PDV 1-67 and PDV 16-15 was $93.6-91.4 \%$ by nucleotide sequences. Isolates of this group were more similar to each other $-95.97 \%$. The overall mean identity of all isolates of the first group was $93.41 \%\left(s_{e}=0.3\right)$.

The second group was formed only by isolates of sweet cherry as the host plant while the geographical distribution of these isolates was different. In most previous studies, no grouping based on the host plant or geographical origin was observed (Vaskova et al., 2000; Pallas et al., 2012, Öztürk \& Çevik, 2015, Predajňa et al., 2017). While study of PDV isolates from Turkey revealed four groups. The first and second groups contained only isolates of cherry and almond, respectively, while the third and fourth contained isolates extracted from different host plants (Ulubaş Serçe et al., 2009). Identity of this group with PDV 1-67 and PDV 16-15 isolates ranged from 90.9 to $85.9 \%$ by nucleotide sequences. In general, this group was the most distant in nucleotide sequences with the mean identity of the isolates $93.67 \%\left(s_{e}=0.6\right)$.

Construction of the phylodendrogram based on amino acid sequences showed similar results of isolate grouping into two groups. The same results were obtained in a previous study, which analyzed the amino acid sequences of the $\mathrm{CP}$ gene of isolates contained in the GenBank (Pallas et al., 2012).

Thus, PDV isolates that differ in molecular characteristics may circulate on the territory of Ukraine, although they are extracted from host plants of the same species and have a common geographical origin.

\section{CONCLUSIONS}

Based on of nucleotide sequence analysis of PNRSV, it was determined that isolates belonging to PV-96 and PV-32 groups circulate in Zaporizhzhya and Kyiv regions, respectively.

The manifestation of symptoms may differ based on the group explaining the fact that some infected PNRSV trees show no signs of viral infection.

Clustering of PNRSV isolates confirms the presence of three groups that do not relate to the host plant and geographical distribution. Nucleotide substitutions affecting clustering of isolates have been established.

Phylogenetic analysis revealed that PDV isolates formed two groups with two subgroups, and in our case the second group included isolates only from sweet cherry from different countries.

High similarity of Ukrainian PDV isolates with each other and the distance with known isolates may indicate the existence of a separate geographical origin based group.

This research should be continued with the involvement of a wider range of isolates from other regions of Ukraine as well as other crops.

\section{REFERENCES}

Amari, K., Burgos, L., Pallás, V., \& Sánchez-Pina, M. A. (2007). Prunus necrotic ringspot virus early invasion and its effects on apricot pollen grains performance. Phytopathology, 97, 892-899. http://doi.org/10.1094/PHYTO-97-8-0892

Aparicio, F., \& Pallás, V. (2002). Molecular variability analysis of the RNA 3 of fifteen isolates of Prunus necrotic ringspot virus sheds light on the minimal requirements for the synthesis of the subgenomic RNA. Virus Genes, 25, 75-84. http://doi.org/10.1023/a:1020126309692

Aparicio, F., Sánchez-Navarro, J. A., \& Pallás, V. (2006). In vitro and in vivo mapping of the Prunus necrotic ringspot virus coat protein C-terminal dimerization domain by bimolecular fluorescence complementation. Journal of General Virology, 87, 1745-1750. http://doi.org/10.1099/vir.0.81696-0

Aparicio, F., Sanchez-Pina, M. A., Sanchez-Navarro, J. A., \& Pallas, V. (1999). Location of Prunus necrotic ringspot ilarvirus within pollen grains of infected nectarine trees: evidence from RT-PCR, dot-blot and in situ hybridisation. European Journal of Plant Pathology, 105, 623-627

Bachman, E. J., Scott, S. W., Xin, G., \& Vance, V. B. (1994). The Complete Nucleotide Sequence of Prune Dwarf Ilarvirus RNA 3: Implications for Coat Protein Activation of Genome Replication in Ilarviruses. Virology, 201(1), 127-131. http://doi.org/10.1006/viro.1994.1272

Çağlayan, K., Ulubas-Serce, C., Gazel, M., \& Varveri, C. (2011). Prune dwarf virus. In A. Hadidi, M. Barba, T. Candresse, W. Jelkmann (Eds.), Virus and Virus-Like Diseases of Pome and Stone Fruits (pp. 199-205). American Phytopathological Society, St. Paul, MN.

Codoñer, F. M., \& Elena, S. F. (2006). Evolutionary relationships among members of the Bromoviridae deduced from whole proteome analysis. Archives of Virology, 151(2), 299-307. http://doi.org/10.1007/s00705-005-0628-4

Felsenstein, J. (1985). Confidence limits on phylogenies: An ap- 
proach using the bootstrap. Evolution, 39, 783-791. https:// doi.org/ 10.2307/2408678

Hammond R. W. (2003). Phylogeny isolates of Prunus necrotic ringspot virus from the ilarvirus ringtest and identification of group-specific features. Archives of Virology, 148(6), 1195-1210. http://doi.org/10.1007/s00705-003-0013-0

Jakab-Ilyefalvi, Zs., Pamfil, D., \& Craciun, C. (2011). Transmission electron microscopy of Plum pox virus, Prunus necrotic ringspot virus, Prune dwarf virus in plum (Prunus domestica, L.). Journal of Horticulture, Forestry and Biotechnology, 15(1), 120- 125.

Kamenova, I., Borisova, A., \& Popov, A. (2019). Incidence and genetic diversity of Prune dwarf virus in sweet and sour cherry in Bulgaria. Biotechnology \& Biotechnological Equipment, 33(1), 980-987. https://doi.org/10.1080/13102818.20 19.1637278

Kozieł, E., Bujarski, J., \& Otulak, K. (2017). Molecular Biology of Prune Dwarf Virus - A Lesser Known Member of the Bromoviridae but a Vital Component in the Dynamic Virus-Host Cell Interaction Network. International Journal of Molecular Sciences, 18(12), 2733. http://doi.org/10.3390/ ijms18122733

Kumar, S., Stecher, G., Li, M., Knyaz, C., \& Tamura K. (2018). MEGA X: Molecular Evolutionary Genetics Analysis across computing platforms. Molecular Biology and Evolution, 35, 1547-1549. https://doi.org/10.1093/molbev/msy096

Maliogka, V. I., Dovas, C. I., \& Katis, N. I. (2007). Demarcation of ilarviruses based on the phylogeny of RNA2-encoded RdRp and generic ramped annealing RT-PCR. Archives of Virology, 152(9), 1687-1698. https://doi.org/10.1007/ s00705-007-0995-0

Massart, S., Brostaux Y., Barbarossa, L., César, V., Cieslinska, M., Dutrecq, O., ... Jijakli M. H. (2008). Inter-laboratory evaluation of a duplex RT-PCR method using crude extracts for the simultaneous detection of Prune dwarf virus and Prunus necrotic ringspot virus. European Journal of Plant Pathology, 122, 539-547. https://doi.org/10.1007/ s10658-008-9322-1

Menzel, W., Jelkmann, W., \& Maiss, E. (2002). Detection of four apple viruses by multiplex RT-PCR assays with coamplification of plant mRNA as internal control. Journal of Virological Methods, 99(1-2), 81-92. https://doi.org/10.1016/ s0166-0934(01)00381-0

Nemeth, M. (1986). Virus, Mycoplasma and Rickettsia Diseases of Fruit Trees. Hungary Martinus Nijhoff Publishers, The Netherlands and Akademiai Kiado.

Nyland, G., Gilmer, R. M., \& Moore, J. D. (1976). "Prunus" ringspot group. In R. M. Gilmer, J. D. Moore (Eds.) Virus Diseases and Non-Infectious Disorders of Stone Fruits in North America, (pp. 104-132). USDA, Washington Agriculture Handbook.

Öztürk, Y. \& Çevik, B. 2015. Genetic Diversity in the Coat Protein Genes of Prune dwarf virus Isolates from Sweet Cherry Growing in Turkey. Plant Pathology Journal, 31, 41-49. http://doi.org/10.5423/ppj.oa.07.2014.0063

Pallas, V., Aparicio, F., Herranz, M., Amari, K., Sanchez-Pina, M., Myrta, A., \& Sanchez-Navarro, J. (2012). Ilarviruses of Prunus spp.: a continued concern for fruit trees. Phytopa- thology, 102, 1108-1120. https://doi.org/10.1094/PHYTO02-12-0023-RVW

Pallas, V., Aparicio, F., Herranz, M., Sanchez-Navarro, A., \& Scott, W. (2013). The molecular biology of ilarviruses. Advances in Virus Research, 87, 139-181. https://doi. org/10.1016/B978-0-12-407698-3.00005-3

Pavliuk, L., Riaba, I., Udovychenko, K., Triapitsyna, N., \& Bublyk M. (2019). Phyto-virologic state of parent plantings of cherry and mazzard cherry in Ukraine. Bulletin of $A g-$ ricultural Science, 97(7). https://doi.org/20.31073/agrovisnyk201907-3

Predajňa, L., Sihelská, N., Benediková, D., Šoltys, K., Candresse, T., \& Glasa, M. (2017). Molecular characterization of Prune dwarf virus cherry isolates from Slovakia shows their substantial variability and reveals recombination events in PDV RNA3. European Journal of Plant Pathology, 147, 877 885. http://doi.org/10.1007/s10658-016-1055-y

Roossinck M. J., Bujarski, J., Ding, S. W., Hajimarad, R., Hanada, K., Scott, S., \& Tousignant, M. (2005). Bromoviridae. In. C. M. Fauquet, M. A. Mayo, J. Maniloff, U. Desselberger, L. A. Ball (Eds.), Virus Taxonomy. Eight Report of the International Committee on Taxonomy of Viruses (pp. 1049-1058). Elsevier/Academic Press, Amsterdam, Netherlands.

Saitou, N., \& Nei, M. (1987). The neighbor-joining method: A new method for reconstructing phylogenetic trees. Molecular Biology and Evolution, 4, 406-425. https://doi. org/10.1093/oxfordjournals.molbev.a040454

Sala-Rejczak, K., \& Paduch-Cichal, E. (2013). Molecular variability of the coat protein gene of Prunus necrotic ringspot virus isolates. Acta Scientiarum Polonorum Hortorum Cultus, 12(2), 35-42.

Sanchez, R. P., Corts, R. M., Benavides, P. G., \& GómezSánchez, M. A. (2015). Main viruses in sweet cherry plantations of Central-Western Spain. Scientia Agricola, 72(1), 83-86. https://doi.org/10.1590/0103-9016-2014-0140

Scott, S. W., Zimmerman M. T., Ge, X., \& MacKenzie, D. J. (1998). The coat proteins and putative movement proteins of isolates of Prunus necrotic ringspot virus from different host species and geographic origins are extensively conserved. European Journal of Plant Pathology, 104, 155-161. http://doi.org/10.1023/a:1008668129926

Smith, I. M., Dunez, J., Phillips, D. H., Lelliott, R. A., \& Archer, S. A. (1988). European handbook of plant diseases. Oxford (UK): Blackwell Scientific.

Sokhandan-Bashir, N., Kashiha, Z., Koolivand D., \& Eini, O. (2017). Detection and phylogenetic analysis of Prunus necrotic ringspot virus isolates from stone fruits in Iran. Journal of Plant Pathology, 99(3), 717-723. http://doi. org/10.4454/jpp.v99i3.3986

State Service of Statistics of Ukraine. (2019). Areas, gross production, and yields of agricultural crops by their type and by region. Retrieved from http://www.ukrstat.gov.ua/ (in Ukrainian)

Ulubas-Serçe, Ç., Ertunç, F., \& ÖZtürk, A. (2009). Identification and genomic variability of Prune dwarf virus variants infecting stone fruit in Turkey. Journal of Phytopathology, 157, 298-305. https://doi.org/10.1111/j.1439-0434.2008.01486.x

Umer, M., Liu, J., You, H., Xu, C., Dong, K., Luo, N., ... Xu, W. (2019). Genomic, Morphological and Biological Traits 
of the Viruses Infecting Major Fruit. Viruses, 11(6), 515. http://doi.org/10.3390/v11060515

Vaskova, D., Petrzik, K., \& Spak, J. (2000). Molecular variability of the capsid protein of the Prune dwarf virus. European Journal of Plant Pathology, 106, 573-580. http://doi. org/10.1023/A:1008742513754

Verderevskaya, T. D., \& Marinesku, V. G. (1985). Viral and my- coplasmal diseases of fruit crops and grapes. Chisinau: Shtinitsa. (in Russian)

Wells, J. M., \& Kirkpatrick, H. C. (1986). Symptomatology and incidence of Prunus necrotic ringspot virus in peach orchards in Georgia. Plant Disease, 70, 444-447. https://doi. org/10.1094/PD-70-444 